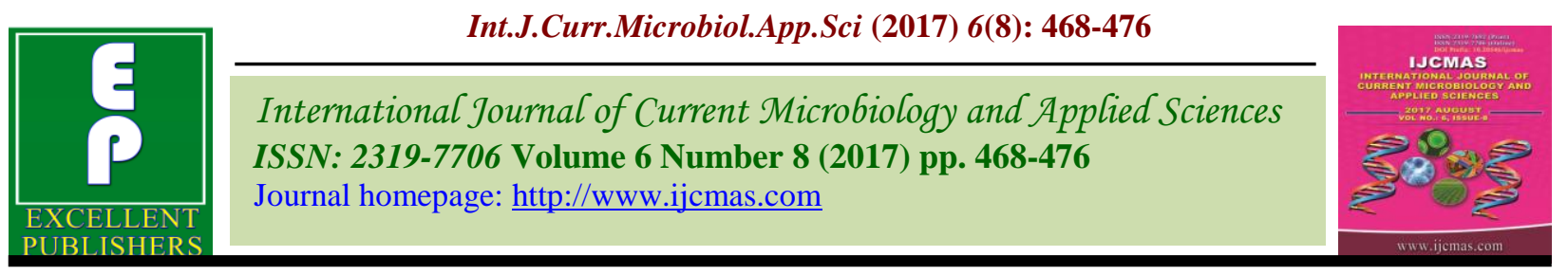

Original Research Article

https://doi.org/10.20546/ijcmas.2017.608.061

\title{
Phenology, Growth and Quality of Sweet Corn (Zea mays saccharata L.) as Influenced by Sowing Dates and Plant Spacing
}

\author{
Rehana Mohi-ud-din ${ }^{1 *}$, Nasir Ahmad Dar ${ }^{1}$, Lal Singh", \\ Tahir Ahmad Sheikh' and Zahoor Ahmad Dar ${ }^{2}$ \\ ${ }^{1}$ Division of Agronomy, ${ }^{2}$ Division of Genetics and Plant Breeding, Sher-e-Kashmir University of \\ Agricultural Sciences and Technology, Shalimar- 190025, Jammu and Kashmir, India \\ *Corresponding author
}

\begin{tabular}{|c|c|}
\hline & A B S T R A C T \\
\hline & \multirow{5}{*}{$\begin{array}{l}\text { The field experiment entitled "Phenology, growth and quality of sweet corn (Zea mays } \\
\text { saccharata L.) As influenced by sowing dates and plant spacing" was carried at SKUAST- } \\
\text { K, Shalimar during kharif season } 2014 \text {. The cultivar Misthi of Sweet corn was chosen for } \\
\text { the study. The experiment comprised of two factors with four sowing dates viz. } 24^{\text {th }} \text { May } \\
\left(\mathrm{D}_{1}\right), 02^{\text {nd }} \text { June }\left(\mathrm{D}_{2}\right), 11^{\text {th }} \text { June }\left(\mathrm{D}_{3}\right) \text { and } 19^{\text {th }} \text { June }\left(\mathrm{D}_{4}\right) \text { as main-plot treatments and three } \\
\text { plant spacing viz. } 60 \mathrm{~cm} \times 20 \mathrm{~cm}\left(\mathrm{~S}_{1}\right), 70 \mathrm{~cm} \times 20 \mathrm{~cm}\left(\mathrm{~S}_{2}\right) \text { and } 80 \mathrm{~cm} \times 20 \mathrm{~cm}\left(\mathrm{~S}_{3}\right) \text { as sub- } \\
\text { plot treatments replicated thrice. Results of the experiment revealed that } 24^{\text {th }} \text { May }\left(\mathrm{D}_{1}\right) \\
\text { sowing recorded significantly highest plant height and number of functional leaves as } \\
\text { compared to other sowing dates. More number of days was taken by sweet corn sown on } \\
24^{\text {th }} \text { May }\left(\mathrm{D}_{1}\right) \text { and accumulated more heat compared to delay sowing. Among plant } \\
\text { spacing, plant height which was significantly superior with } 80 \mathrm{~cm} \times 20 \mathrm{~cm} \text { than } 70 \mathrm{~cm} \times 20 \\
\mathrm{~cm} \text { and } 60 \mathrm{~cm} \times 20 \mathrm{~cm} \text { and more number of days was taken by sweet corn at plant spacing } \\
\text { of } 80 \mathrm{~cm} \times 20 \mathrm{~cm} \text { and accumulated more heat units compared to closer spacing. And non- } \\
\text { significant effect of sowing dates and plant spacing was observed on quality of sweat corn. }\end{array}$} \\
\hline $\begin{array}{l}\text { Maize, Plant } \\
\text { spacing, Quality, } \\
\text { Sowing dates. }\end{array}$ & \\
\hline Article Info & \\
\hline $\begin{array}{l}\text { Accepted: } \\
\text { 04 June } 2017 \\
\text { Available Online: } \\
10 \text { August } 2017\end{array}$ & \\
\hline & \\
\hline
\end{tabular}

\section{Introduction}

In India, maize is one of the top four cereals occupying an area of 7.89 mha with a production of $15.09 \mathrm{mt}$ and productivity of $1904 \mathrm{~kg} \mathrm{ha}^{-1}$. Andhra Pradesh is one of the major maize producing states with a production of $4.15 \mathrm{mt}$ from 0.85 million ha averaging $4073 \mathrm{~kg} \mathrm{ha}{ }^{-1}$ (CMIE, 2010). Approximately $25 \%$ of the total corn produced is being used for human consumption either in fresh or processed form. Sweet corn is emerging as one of the important enterprises projecting diversified and value added uses of maize. Steam boiled green cobs of sweet corn has gained immense popularity among the urbanites as a favourite dish, resulting in premium price for growers. Diversification and value addition of sweet corn are currently contemplated in view of rapid growth in the food processing industry.

Continuous and growing demand for fresh sweet corn cobs has led to cultivation of sweet corn round the year varied soil conditions and management practices. In Andhra Pradesh, lower yield levels of maize in general and sweet corn in particular could be attributed to sub optimal population stand, inappropriate fertilizer dose, and lack of 
suitable cultivars with good seed and processing qualities.

Presently greater emphasis is being given on enhancing the productivity and quality of sweet corn through suitable agro techniques with an intention to augment the net profits to farming community dwelling in the vicinity of big cities and metropolis (Shanti et al., 2012).

Exploring possible combinations of sowing dates and plant spacing that would enable the urban farmer to efficiently utilize scarce resources and reduce the cost of cultivation is worth attempting.

Such a backdrop necessarily calls for certain reoriented research efforts commensurate with modern needs with reference to sweet corn. Therefore, the present investigation was planned to understand the ultimate phenology, growth and quality of sweat corn (Zea mays saccharata 1.) as influenced by sowing dates and plant spacing.

\section{Materials and Methods}

The field experiment entitled "phenology, growth and quality of sweet corn (Zea mays saccharata $\mathrm{L}$.) As influenced by sowing dates and plant spacing" was carried at SKUASTK, Shalimar during kharif season 2014. Sweet corn $c v$. Misthi was chosen for the study.

The experiment comprised of two factors with four sowing dates viz. $24^{\text {th }}$ May $\left(D_{1}\right), 02^{\text {nd }}$ June $\left(\mathrm{D}_{2}\right), 11^{\text {th }}$ June $\left(\mathrm{D}_{3}\right)$ and $19^{\text {th }}$ June $\left(\mathrm{D}_{4}\right)$ as main-plot treatments and three plant spacing viz. $60 \mathrm{~cm} \times 20 \mathrm{~cm}\left(\mathrm{~S}_{1}\right), 70 \mathrm{~cm} \times 20 \mathrm{~cm}$ $\left(\mathrm{S}_{2}\right)$ and $80 \mathrm{~cm} \times 20 \mathrm{~cm}\left(\mathrm{~S}_{3}\right)$ as sub-plot treatments replicated thrice.

Number of days taken by sweet corn crop to reach various phenological stages till completion of picking (harvest) was observed throughout crop growth period and Growing Degree Days (GDD) was calculated from sowing date to completion of harvest according to the formula:

$$
\begin{aligned}
& \mathrm{GDD}= \\
& \text { Max. Temperature }+ \text { Min. Temperature } \\
& -2
\end{aligned}
$$

Where base temperature is $10^{\circ} \mathrm{C}$

\section{Plant height}

Plant height of five tagged plants in penultimate rows of each plot at 10 days interval DAS was recorded and averaged to plant height in centimeters. The plant height was taken from the base of soil surface to fully opened top leaf.

\section{Functional leaves}

Total number of functional leaves (green leaves) of 10 randomly marked plants in each plot were counted at harvest, averaged and recorded as number of functional leaves plant ${ }^{-1}$.

\section{Quality parameters}

Green cob samples of $50 \mathrm{~g}$ each collected from picked lot of each plot and $1 \mathrm{~kg}$ fodder sample collected from harvest lot of each plot were sun dried and then oven dried at 60$65^{\circ} \mathrm{C}$ for $36-48$ hours to a constant weight.

The dry weight of samples was recorded in grams. The samples were ground and subsequently used for chemical analysis.

\section{Protein content (\%)}

Protein content of cob and fodder was determined by multiplying respective nitrogen content with a factor 6.25 . 


\section{TSS of cob and fodder}

The hand refractometer of range (0-32) ${ }^{\circ}$ Brix (Erma Make Japan) was used to determine total soluble solids of fresh sweet corn samples. The values were corrected at $20^{\circ} \mathrm{C}$ (Ranganna, 1986).

\section{Ascorbic acid (mg)}

Vitamin $\mathrm{C}$ was estimated by the method as described by Ranganna (1986) using 2, 6 dichlorophenol indophenol as dye.

Dye factor was first calculated by titrating 5 $\mathrm{ml}$ standard ascorbic acid plus $5 \mathrm{ml}(3 \%)$ metaphosphoric acid against 2,6, dichlorophenol indophenol till pink colour appeared and volume used noted.

Dye factor $=\frac{0.5}{\text { Titre value }}$

The vitamin $\mathrm{C}$ of the sample was estimated by taking $10 \mathrm{ml}$ of sample, volume made upto $100 \mathrm{ml}$ with $3 \%$ metaphosphoric acid and filtered.

Then aliquot of $10 \mathrm{ml}$ was taken in titration flask and titrated against dye 2, 6 dichlorophenol indophenol till light pink colour appeared (which should persist for 15 seconds).

Samples preserved by KMS (potassium metabisulphite) were analyzed after eliminating the interface of sulphur dioxide by using formaldehyde condensation procedure. Vitamin $\mathrm{C}$ was calculated using equation as:

Ascorbic acid $(\mathrm{mg} / 100 \mathrm{~g})=$

Titre value $\times$ Dye factor $\times$ Vol. made up

$\mathrm{ml}$ of filtrate taken for estimation $\times$ wt. of sample

\section{Retinol (mg)}

Vitamin A is estimated by the colorimetric method using antimony trichloride which reacts with vitamin $\mathrm{A}$ in chloroform solution a blue colour develops.

If the solution containing vitamin for analysis is freed from saponifiable material and an appropriate color filter is used on photoelectric colorimeter this reaction appears fairly reliable for vitamin $\mathrm{A}$. The vitamin $\mathrm{A}$ is estimated by the colorimetric readings by the use of a standard curve.

Vitamin A/g sample = final volume/sample weight

\section{Results and Discussion}

The field experiment was conducted during year 2014 at the Experimental Farm of the Division of Agronomy, Sher-e-Kashmir University of Agricultural Sciences and Technology of Kashmir. The detailed description of treatment effects on various growth characters of sweet corn was studied.

Delayed sowing decreased the number of days to reach various phenological stages of sweet corn. This can be attributed to the fact that lower temperature and accumulation of more heat units with early sowing resulted in delayed germination and emergence and more number of days to reach silking, tasseling and harvesting (Tables 1 and 2). The results are in conformity with Kim et al., (1999), Khan et al., (2002) and Williams (2008). Plant spacing of $80 \mathrm{~cm} \times 20 \mathrm{~cm}\left(\mathrm{~S}_{3}\right)$ took more days for tasseling, silking and harvest completion than other spacings (Table 1). The probable reason may be that plants under narrow spacing had increased competition for sunlight, nutrients and moisture which delayed its shift to reproductive phase. These effects are reflected in the length of harvesting period, as harvest period decreased with decrease in 
spacing. Similar findings were reported by Sukanya et al., (1999).

There was significant and consistent increase in plant height of sweet corn till 65 DAS (Table 3). Delayed sowing resulted in decrease in the rate of increase in plant height. The reason for the fact is that with delayed sowing the temperature was high which was conducive for the increase in the growth rate.

Earlier sowing resulted in taller plants compared to delay sowing because of the fact that the early sown crop got longer time period to utilize available growth resources. Similar results were reported by Imholte and Carte (1987) and Morin and Dormency (1993). The results are in agreement with observation of Moosavi et al., (2012) who reported that there is a significant decline in the plant height with the delay in sowing time of corn, this significant decrease in plant height and stem traits following the delay in sowing can be associated with higher temperatures that the plants at third and fourth sowing dates experienced, which limited their growing period and assimilate building because of the early maturity of plants. There was significant and consistent increase in plant height of sweet corn till 65 DAS (Table 3). Plant height was higher under wider spacing compared to closer spacing. This may be due to the reason that under closer spacing regimes, inter plant competition for light, moisture, nutrients and other environmental sources are more and hence decreased photosynthesis, assimilates production and its partitioning, that finally resulted in reduction of plant height. Similar results were reported by Peykarestan and Seify (2012). Number of functional leaves per plant decreased with delayed sowing (Table 4). This can be attributed to the fact that delayed sowing results in the reduction of photoperiod which ultimately results in the decrease in the number of leaves. The results are confirmed by Beiragi et al., (2011) who reported that the total number of leaves decreased with delayed sowing. Number of functional leaves plant $^{-1}$ was higher with wider spacing compared to narrow spacing (Table 4). The wider spacing may have allowed better penetration of sunlight in the leaf canopy resulting in delayed leaf senescence percentage. Thakur et al., (1997) reported similar findings.

The results of the experiment revealed that quality parameters viz. protein content, total soluble sugars, vitamin $\mathrm{C}$ and vitamin $\mathrm{A}$ of sweet corn were not influenced by sowing dates and plant spacing (Table 5). However, higher values of these parameters were recorded by early sowing of sweet corn which might be due to improved growth and higher temperature with delayed sowing which resulted in less assimilation of synthates. These results are in confirmation with Darby and Laver (2002) and Mokhtarpour et al., (2013) reported that delayed sowing resulted in lower quality of sweet corn.

However, the highest value of these parameters were recorded at wider plant spacing which might be due to lower plant population per unit area, vigorous growth, more nutrient plant ${ }^{-1}$ without competition that results in higher concentration of assimilates in plant. Similar findings were reported by Verma and Joshi (1998).

Days to reach various phenological stages reduced with delayed sowing of sweet corn from $24^{\text {th }}$ May $\left(D_{1}\right)$ to $19^{\text {th }}$ June $\left(D_{4}\right)$. Plant spacing of $80 \times 20 \mathrm{~cm} \quad\left(\mathrm{~S}_{3}\right)$ recorded significantly more days to reach tasseling, silking, and harvesting respectively in comparison to $60 \times 20 \mathrm{~cm}\left(\mathrm{~S}_{1}\right)$ plant spacing.

Early sowing $24^{\text {th }}$ May $\left(D_{1}\right)$ accumulated more heat to reach the harvesting stage than delayed sowing $19^{\text {th }}$ June $\left(\mathrm{D}_{4}\right)$. Plant spacing of $80 \times 20 \mathrm{~cm}\left(\mathrm{~S}_{3}\right)$ accumulated more heat units to reach harvesting stage than $60 \times 20$ $\mathrm{cm}\left(\mathrm{S}_{1}\right)$ spacing. 
Table.1 Days taken to reach different phenological stages of sweet corn (Zea mays saccharata L.) as influenced by sowing dates and plant spacing

\begin{tabular}{|c|c|c|c|c|c|c|c|}
\hline \multicolumn{2}{|c|}{ TREATMENTS } & \multicolumn{5}{|c|}{ Growth stages } & \multirow[b]{2}{*}{ Harvesting } \\
\hline & & Germination & Emergence & Knee High & Tasseling & Silking & \\
\hline \multicolumn{8}{|c|}{ MAIN PLOT SOWING DATE } \\
\hline $24^{\text {th }}$ MAY & $\left(D_{1}\right)$ & 7 & 13 & 35 & 65 & 71 & 96 \\
\hline $2^{\text {nd }} \mathrm{JUNE}$ & $\left(D_{2}\right)$ & 7 & 12 & 34 & 65 & 71 & 96 \\
\hline $11^{\text {th }} \mathrm{JUNE}$ & $\left(D_{3}\right)$ & 5 & 10 & 34 & 63 & 68 & 94 \\
\hline $19^{\text {th }}$ JUNE & $\left(\mathrm{D}_{4}\right)$ & 5 & 10 & 33 & 63 & 67 & 93 \\
\hline \multicolumn{8}{|c|}{ SUB PLOT PLANT SPACING } \\
\hline $60 \times 20(\mathrm{~cm})$ & $\left(\mathrm{S}_{1}\right)$ & 6 & 12 & 33 & 64 & 69 & 94 \\
\hline $70 \times 20(\mathrm{~cm})$ & $\left(\mathrm{S}_{2}\right)$ & 6 & 12 & 34 & 64 & 69 & 95 \\
\hline $80 \times 20(\mathrm{~cm})$ & $\left(\mathrm{S}_{3}\right)$ & 6 & 12 & 34 & 65 & 70 & 95 \\
\hline
\end{tabular}

Table.2 GDD (Growing degree days) of sweet corn (Zea mays saccharata L.) as influenced by sowing dates and plant spacing

\begin{tabular}{|c|c|c|c|c|c|c|c|c|}
\hline \multirow{2}{*}{\multicolumn{2}{|c|}{ TREATMENTS }} & \multicolumn{7}{|c|}{ Growth stages } \\
\hline & & \multirow[t]{2}{*}{ Germination } & Emergence & Knee High & \multirow{2}{*}{$\begin{array}{l}\text { Tasseling } \\
\text { G DATE }\end{array}$} & \multirow[t]{2}{*}{ Silking } & \multirow[t]{2}{*}{ Harvesting } & \multirow[t]{2}{*}{ Total GDD } \\
\hline \multicolumn{4}{|c|}{ MAIN PLOT SOWING DATE } & & & & & \\
\hline $24^{\text {th }}$ MAY & $\left(\mathrm{D}_{1}\right)$ & $(52.55)$ & $(49.80)$ & $(234.75)$ & $(398.60)$ & $(91.60)$ & $(306.60)$ & 1125.35 \\
\hline $2^{\text {nd }} J U N E$ & $\left(\mathrm{D}_{2}\right)$ & $(66.05)$ & $(48.20)$ & $(244.80)$ & $(440.50)$ & $(82.25)$ & $(242.20)$ & 1124.00 \\
\hline $11^{\text {th }} \mathrm{JUNE}$ & $\left(D_{3}\right)$ & $(51.50)$ & $(54.75)$ & $(286.15)$ & $(417.65)$ & $(58.50)$ & $(214.25)$ & 1082.80 \\
\hline $19^{\text {th }} \mathrm{JUNE}$ & $\left(D_{4}\right)$ & $(50.75)$ & $(57.05)$ & $(286.55)$ & $(422.45)$ & $(44.50)$ & $(195.15)$ & 1056.45 \\
\hline \multicolumn{9}{|c|}{ SUB PLOT PLANT SPACING } \\
\hline $60 \times 20(\mathrm{~cm})$ & $\left(\mathrm{S}_{1}\right)$ & $(55.66)$ & $(59.96)$ & $(240.76)$ & $(431.00)$ & $(63.96)$ & $(241.55)$ & 1092.89 \\
\hline $70 \times 20(\mathrm{~cm})$ & $\left(\mathrm{S}_{2}\right)$ & $(55.66)$ & $(59.96)$ & $(240.76)$ & $(431.00)$ & $(63.96)$ & $(238.88)$ & 1089.86 \\
\hline $80 \times 20(\mathrm{~cm})$ & $\left(\mathrm{S}_{3}\right)$ & $(55.66)$ & $(59.96)$ & $(254.21)$ & $(432.12)$ & $(61.02)$ & $(237.50)$ & 1100.47 \\
\hline
\end{tabular}


Table.3 Plant height $(\mathrm{cm})$ of sweet corn (Zea mays saccharata L.) as influenced by sowing dates and plant spacing at different growth stages

\begin{tabular}{|c|c|c|c|c|c|c|c|c|c|c|}
\hline \multirow{2}{*}{\multicolumn{2}{|c|}{ TREATMENTS }} & \multicolumn{9}{|c|}{ Growth stages } \\
\hline & & $15 \mathrm{DAS}$ & $25 \mathrm{DAS}$ & $35 \mathrm{DAS}$ & $45 \mathrm{DAS}$ & $55 \mathrm{DAS}$ & $65 \mathrm{DAS}$ & $75 \mathrm{DAS}$ & $85 \mathrm{DAS}$ & $95 \mathrm{DAS}$ \\
\hline \multicolumn{11}{|c|}{ MAIN PLOT SOWING DATE } \\
\hline $24^{\text {th }}$ MAY & $\left(D_{1}\right)$ & 14.00 & 24.63 & 54.95 & 100.11 & 127.44 & 161.26 & 205.35 & 210.88 & 214.66 \\
\hline $2^{\text {nd }} \mathrm{JUNE}$ & $\left(\mathrm{D}_{2}\right)$ & 14.11 & 24.72 & 55.14 & 100.11 & 131.55 & 167.97 & 204.22 & 207.55 & 211.77 \\
\hline $11^{\text {th }} \mathrm{JUNE}$ & $\left(D_{3}\right)$ & 19.00 & 27.10 & 58.01 & 112.44 & 149.55 & 182.20 & 193.44 & 202.55 & 205.55 \\
\hline $19^{\text {th }} \mathrm{JUNE}$ & $\left(\mathrm{D}_{4}\right)$ & 19.00 & 28.44 & 61.14 & 120.33 & 154.11 & 187.67 & 193.26 & 199.00 & 203.77 \\
\hline \multicolumn{2}{|c|}{ SEm \pm} & 1.17 & 0.72 & $\mathbf{0 . 5 8}$ & 2.07 & 2.10 & 0.76 & 0.34 & 2.06 & 1.58 \\
\hline \multicolumn{2}{|c|}{ C.D $(P \leq 0.05)$} & 4.04 & 2.49 & 2.02 & 7.17 & 7.26 & 2.63 & 1.19 & 7.12 & 5.46 \\
\hline \multicolumn{11}{|c|}{ SUB PLOT PLANT SPACING } \\
\hline $60 \times 20(\mathrm{~cm})$ & $\left(\mathrm{S}_{1}\right)$ & 16.66 & 28.61 & 58.71 & 114.08 & 145.33 & 178.95 & 192.25 & 201.50 & 205.58 \\
\hline $70 \times 20(\mathrm{~cm})$ & $\left(\mathrm{S}_{2}\right)$ & 16.75 & 25.60 & 57.45 & 108.66 & 140.58 & 174.45 & 199.64 & 204.00 & 207.83 \\
\hline $80 \times 20(\mathrm{~cm})$ & $\left(\mathrm{S}_{3}\right)$ & 16.16 & 24.50 & 55.76 & 102.42 & 136.08 & 170.93 & 205.45 & 209.50 & 211.33 \\
\hline \multirow{2}{*}{\multicolumn{2}{|c|}{$\begin{array}{c}\text { SEm } \pm \\
\text { C.D }(P<0.05)\end{array}$}} & 0.19 & 0.71 & 0.55 & 2.17 & 2.17 & 0.75 & 0.33 & 1.25 & 0.87 \\
\hline & & NS & 2.13 & 1.65 & 6.50 & 6.53 & 2.26 & 0.99 & 3.77 & 2.62 \\
\hline
\end{tabular}

Table.4 Number of functional leaves of sweet corn (Zea mays saccharata L.) as influenced by sowing dates and plant spacing at different phenological stages

\begin{tabular}{|c|c|c|c|c|}
\hline \multirow{2}{*}{ Treatments } & \multicolumn{4}{|c|}{ Phenological stages } \\
\hline & Knee high & Tasseling & Silking & Harvest \\
\hline \multicolumn{5}{|c|}{ Main plot Sowing dates } \\
\hline $24^{\text {th }}$ MAY & 9.40 & 14.26 & 15.14 & 13.66 \\
\hline $2^{\text {nd }} \mathrm{JUNE}$ & 9.10 & 14.16 & 14.78 & 13.35 \\
\hline $11^{\text {th }} \mathrm{JUNE}$ & 8.55 & 12.85 & 14.21 & 12.35 \\
\hline $19^{\text {th }} \mathrm{JUNE}$ & 8.20 & 12.85 & 13.98 & 12.28 \\
\hline $\mathrm{SEm} \pm$ & 0.16 & 0.35 & 0.14 & 0.19 \\
\hline C.D $(\mathrm{P} \leq \mathbf{0 . 0 5})$ & 0.55 & 1.22 & 0.50 & 0.66 \\
\hline \multicolumn{5}{|c|}{ SUB PLOT PLANT SPACING } \\
\hline $60 \times 20(\mathrm{~cm})$ & 8.30 & 12.80 & 14.30 & 12.78 \\
\hline $70 \times 20(\mathrm{~cm})$ & 8.92 & 13.54 & 14.43 & 12.84 \\
\hline $80 \times 20(\mathrm{~cm})$ & 9.31 & 14.26 & 14.86 & 13.27 \\
\hline SEm \pm & 0.26 & 0.24 & 0.13 & 0.11 \\
\hline C.D $(\mathrm{P} \leq \mathbf{0 . 0 5})$ & 0.77 & 0.74 & 0.40 & 0.34 \\
\hline
\end{tabular}


Table.5 Effect of sowing dates and plant spacing on protein content (\%) in cob and fodder, total soluble sugars in cob and fodder, Vitamin $\mathrm{C}$ and vitamin $\mathrm{A}$ of sweet corn

\begin{tabular}{|c|c|c|c|c|c|c|c|}
\hline \multicolumn{2}{|c|}{ TREATMENTS } & \multicolumn{2}{|c|}{ Protein content $(\%)$} & \multicolumn{2}{|c|}{ TSS } & \multirow{2}{*}{$\begin{array}{c}\text { Vitamin C } \\
(\mathrm{mg} / 100 \mathrm{~g}) \\
\text { Cob }\end{array}$} & \multirow{2}{*}{$\begin{array}{c}\text { Vitamin A } \\
(\mathrm{mg} / 100 \mathrm{~g}) \\
\mathrm{Cob}\end{array}$} \\
\hline & & Cob & Fodder & Cob & Fodder & & \\
\hline \multicolumn{8}{|c|}{ MAIN PLOT SOWING DATE } \\
\hline $24^{\text {th }}$ MAY & $\left(D_{1}\right)$ & 9.80 & 9.00 & 13.00 & 10.00 & 9.76 & 0.176 \\
\hline $2^{\text {nd }} J U N E$ & $\left(D_{2}\right)$ & 9.78 & 8.96 & 12.66 & 9.98 & 9.76 & 0.160 \\
\hline $11^{\text {th }} \mathrm{JUNE}$ & $\left(D_{3}\right)$ & 9.52 & 8.71 & 11.97 & 9.94 & 9.75 & 0.150 \\
\hline $19^{\text {th }}$ JUNE & $\left(D_{4}\right)$ & 9.32 & 8.64 & 11.97 & 9.94 & 9.74 & 0.146 \\
\hline SEm & & $\mathbf{0 . 3 0}$ & 0.18 & 0.51 & $\mathbf{0 . 0 3}$ & 0.010 & 0.013 \\
\hline C.D $(\mathrm{P} \leq \mathbf{0 . 0 5}$ & & NS & NS & NS & NS & NS & NS \\
\hline \multicolumn{8}{|c|}{ SUB PLOT PLANT SPACING } \\
\hline $60 \times 20(\mathrm{~cm})$ & $\left(\mathrm{S}_{1}\right)$ & 9.33 & 8.76 & 12.40 & 9.95 & 9.76 & 0.168 \\
\hline $70 \times 20(\mathrm{~cm})$ & $\left(\mathrm{S}_{2}\right)$ & 9.34 & 8.81 & 12.40 & 9.96 & 9.75 & 0.158 \\
\hline $80 \times 20(\mathrm{~cm})$ & $\left(\mathrm{S}_{3}\right)$ & 9.36 & 8.90 & 12.41 & 9.99 & 9.75 & 0.156 \\
\hline SEm \pm & & 0.20 & 0.10 & 0.02 & 0.02 & 0.01 & 0.02 \\
\hline C.D $(P \leq 0.05$ & & NS & NS & NS & NS & NS & NS \\
\hline
\end{tabular}


Delayed sowing $19^{\text {th }}$ June $\left(D_{4}\right)$ significantly decreased plant height and number of functional leaves, whereas significantly higher values of these attributes were recorded with early sowing $24^{\text {th }}$ May $\left(D_{1}\right)$ compared to delayed sowing $19^{\text {th }}$ June $\left(D_{4}\right)$. Plant spacing of $80 \times 20 \mathrm{~cm}\left(\mathrm{~S}_{3}\right)$ recorded highest plant height than $60 \times 20 \mathrm{~cm}\left(\mathrm{~S}_{1}\right)$ spacing. Lowest plant height was recorded with $60 \times 20 \mathrm{~cm}\left(\mathrm{~S}_{1}\right)$ spacing. Plant spacing of $80 \times 20 \mathrm{~cm}\left(\mathrm{~S}_{3}\right)$ recorded higher number of functional leaves than narrow plant densities. Lower numbers of functional leaves were recorded with $60 \times 20 \mathrm{~cm}\left(\mathrm{~S}_{1}\right)$ spacing.

Protein content, total soluble sugars, vitamin $\mathrm{C}$ and vitamin $\mathrm{A}$ were not significantly affected by sowing dates. However, the uptake of nutrients in grain and fodder showed a significant improvement with early sowing dates $24^{\text {th }}$ May $\left(\mathrm{D}_{1}\right)$. No significant effect was observed with plant spacing on protein content, total soluble sugars, vitamin $\mathrm{C}$ and vitamin A. At plant spacing of $80 \times 20$ $\mathrm{cm}\left(\mathrm{S}_{3}\right)$ recorded higher values than $60 \times 20$ $\mathrm{cm}\left(\mathrm{S}_{1}\right)$ spacing.

\section{References}

Beiragi, M.A., Khosarani, S.K., Shojaei, S.H., Dadresan, M., Mostafavi, K. and Golbashy, M. 2011. A study on effect of planting dates on Growth and Yield of 18 corn Hybrids (Zea mays L). American Journal of Experimental Agriculture, 13: 110-120.

CMIE, 2010. Center of Monitoring India Economy Pvt. Ltd, Apple Apetile, Mumbai.

Darby, H. and Laver, J. 2002. Planting date and hybrid influence on corn forage yield and quality. Agronomy Journal 98(3-4): 281-289.

Imholte, A.A. and Carte, P.R. 1987. Planting date and tillage effects on corn. Agronomy Journal, 79: 746-751

Khan, N., Qasim, M., Ahmed, F., Naz, F. and
Khan, R. 2002. Effect of sowing dates on yield of maize under agroclimatic conditions of Kaghan valley. Asian Journal of Plant Sciences, 1: 146-147.

Kim, J.D., Kim, D.A., Park, H.S. and Kim, S.G. 1999. Effect of planting dates and hybrid on forage yield and quality of corn for silage. Korean Society of Grassland Science, 19: 211-220

Mokhtarpour, H., Feyzbakhsh, M.T., Mossavat, S.A. and Pourfarid, A. 2013. Effects of sowing dates and plant density on qualitative and quantitative yield of sweet corn forage in summer sowing. Asian Journal of Exp. Biol. Sci., 14(2): 251-255.

Moosavi, S.G., Seghatoleslami, M.J. and Moazeni, A. 2012. Effect of planting date and plant density on morphological traits, LAI and forage corn yield. International Research Journal of Applied and Basic Science, 3(1): 57-63

Morin, C.D. and Dormency, H. 1993. Limits of a simple model to predict yield losses in maize. Weed Research, 33: 248-261.

Peykarestan, B. and Seify, M. 2012. Sowing date effect on growth and yield attributes of corn (Zea mays evertasturt) grown under different densities. African Journal of Agricultural Research, 7(31): 4427-4431.

Ranganna, S. 1986. Handbook of analysis and quality control for fruit and vegetable products. $1^{\text {st }}$ Edition, New Delhi: McGraw-Hill.

Shanti, J., Sreedhar, M., Durga, K.K., Keshavulu, K., Bhave. M.H.V. and Ganesh, M. 2012. Influence of plant spacing and fertilizer dose on yield parameters and yield of sweet corn (Zea mays saccharata L.) International Journal of Bio-resource and Stress Management, 3(1):040-043.

Sukanya, T.S., Nanjappa, H.V. and Ramachandrappa, B.K. 1999. Effect of spacings on the growth, development 
and yield of baby corn (Zea mays L.) varieties. Karnataka Journal of Agricultural Sciences 12(1-4): 10-14.

Thakur, D.R., Prakash, O., Kharwara, P.C. and Bhalla, S.K. 1997. Effect of nitrogen and plant spacing on growth, yield and economics of baby corn (Zea mays). Indian Journal of Agronomy 42(3): 479-483.
Verma, S.K. and Joshi, V.P. 1998. Effect of nitrogen and seed rate on leaf area index, nitrogen content, nitrogen uptake and dry matter yield of teosinte. Forage Research 24(1): 45-47

Williams, M.M. 2008.Sweet corn growth and yield responses to planting dates of the north central United States. Hort Science 43(6): 1775-1779.

\section{How to cite this article:}

Rehana Mohi-ud-din, Nasir Ahmad Dar, Lal Singh, Tahir Ahmad Sheikh and Zahoor Ahmad Dar. 2017. Phenology, Growth and Quality of Sweet Corn (Zea mays saccharata L.) as Influenced by Sowing Dates and Plant Spacing. Int.J.Curr.Microbiol.App.Sci. 6(8): 468-476. doi: https://doi.org/10.20546/ijcmas.2017.608.061 